\title{
O potrzebie religii w ponowoczesnym świecie (refleksje socjologa)
}

\author{
On the Need of Religion in the Postmodern World \\ (the Reflections of a Sociologist)
}

Zainteresowanie religia było zawsze silniejsze i głębsze niż innymi dziedzinami kultury, gdyż jest to fenomen powszechny oraz wszechstronnie powiązany $z$ wszelkimi przejawami indywidualnego i społecznego życia ludzkiego

Zofia Zdybicka [1978: 21]

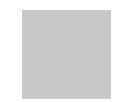

\begin{abstract}
Abstrakt: Autorka, wychodząc od wskazania różnych ujęć i funkcji religii, dowodzi, że współczesnego człowieka Zachodu nadal można uznać za homo religiosus, a religia nie traci na swoim znaczeniu w świecie późnej ponowoczesności. Autorka, odwołując się do nauk socjologicznych, które poprzez stwarzanie nowych perspektyw badawczych, pozwalają na wyjaśnienie różnorodnych przemian religijności zachodzących we współczesnym świecie, ukazuje, że pomimo zachodzących przeobrażeń społecznych organizacji ludzkiego świata, religia wciąż ma szansę być istotną siłą społeczną i rozważa potencjalne „scenariusze przyszłości”.
\end{abstract}

Słowa kluczowe: religia, ponowoczesność, socjologia religii

Abstract: The Author first shows different perspectives and functions of religion, then she argues that the modern Western man can still be considered homo religiosus and religion does not lose its importance in late postmodernity. Referring to sociological sciences, which, by creating new research perspectives, make it possible to explain various transformations of religiousness happening in today's world, the Author shows that despite social transformations of the human world, religion is still able to be a key social power. Then she considers potential "scenarios of the future."

Key words: religion, postmodernity, sociology of religion 


\section{O potrzebie religii}

Obecność pewnych form, określanych jako religijne we wszystkich typach społeczeństw, nie budzi wątpliwości, choć nastręcza sporo trudnych pytań i znacznie mniej zadowalających odpowiedzi. Fenomen religii opiera się na fundamencie tajemnicy bytu - w tym kontekście człowiek jawi się jako istota poszukująca ostatecznego celu egzystencji, nadającego sens jego życiu. Koresponduje to z przeświadczeniem, że współczesny człowiek Zachodu pomimo wolności od wszelkiego kairôs (wypełnienia czasu), tak dobrze znanemu chrześcijaństwu, nadal jest homo religiosus odczuwającym głód wiary, nadziei i miłości [Mikołejko 2014: 11-14]. Religia jest zarówno faktem o charakterze jednostkowym, psychologicznym, jak i społecznym, kulturowym. Dla człowieka wierzącego jest także faktem „ontycznym”, ponieważ dotyka relacji człowieka i Boga. W interpretacji fenomenologicznej (R. Otto, M. Scheler) świętość (sacrum) występuje jako czynnik pierwotny i centralny, leżący u podłoża wszystkich historycznych religii. Ten pierwiastek wzniosły i całkowicie odmienny od tego, co nieświęte napełnia człowieka przerażeniem i lękiem (mysterium tremendum), a jednocześnie fascynuje go i pociąga (mysterium fascinosum), nie jest jednak przez niego dowolnie wywoływany [Otto 1993: 35-37].

Odmienne stanowisko reprezentują zwolennicy teorii psychologicznych (W. James, Z. Freud, C. G. Jung), uznający religię za projekcję potrzeb psychicznych (podświadomości) człowieka dążącego do udoskonalenia się i rozwoju, tak na płaszczyźnie jednostkowej, jak i zbiorowej. Natomiast reprezentanci myśli socjologicznej, związanej z funkcjonalną interpretacją religii, upatrują w niej formę komunikacji, utrzymującą integrację społeczeństwa i ciągłość pokoleniową (E. Durkheim, B. Malinowski) [por. Durkheim 1990; Malinowski 1990]. Religijne wierzenia, symbole i zespoły norm regulujących ludzkie postępowanie, postrzegane są jako istotny element więzi społecznej. Religia jest traktowana jako jedna $\mathrm{z}$ form zinstytucjonalizowanego zachowania ludzi, sprzyjająca utrzymaniu równowagi osobowościowej. Odpowiada ona trzem podstawowym cechom ludzkiej egzystencji: „kontekstowi niepewności”, „kontekstowi niemożności” oraz „sytuacji braku” (T. O’Dea) [por. Chlewiński 1982: 39-42]. Człowiek żyje w warunkach ograniczonego poczucia bezpieczeństwa i możliwości jego kontroli (bezsilność ludzkiego istnienia); w społeczeństwie, w którym doświadcza deficytu podstawowych dóbr (np. czystej wody, pożywienia, trwałego pokoju), toteż religia przeciwdziała tym niekorzystnym zjawiskom, pełniąc określone funkcje. Religia, poprzez dostarczenie układu odniesienia przekraczającego empirycznie dostępne „tu i teraz”, pozostaje oparciem dla jednostek w sytuacji niepewności 
losu, niepowodzeń i rozczarowań; włącza je do grup, integrując z uznawanymi wartościami i normami, co przyczynia się do wzrostu kontroli społecznej i ograniczenia dewiacji; sprzyja samookreśleniu siebie (identyfikacji), przeprowadzając jednostki poprzez różne fazy życia. Społeczne znaczenie religii nie ogranicza się jednak do stabilizacji istniejącego porządku społecznego, paradoksalnie, pełniona przez nią funkcja profetyczna odsłania napięcia między ideą a strukturą i upomina się o realizację wysokich standardów normatywnych w każdych warunkach historycznych. Negatywne strony omówionych funkcji religii mogą wiązać się z konfliktogennością (w szerszej skali społecznej), czy powstawaniem autorytarnych osobowości, co w znacznej mierze ogranicza efektywność adaptacyjną systemu społecznego.

Współczesnych badaczy interesują społeczne mechanizmy kreujące i odtwarzające sferę symboli religijnych. Dla Leszka Kołakowskiego, religia jest w istocie świadomością ludzkiej niesamowystarczalności, pojawia się w następstwie rozziewu między celami a środkami działania [Kołakowski 1987]. Nowoczesność podejmuje próbę (czy udaną?) dawania sobie rady bez Boga - ,ludziom troszczyć się wypada o takie tylko sprawy, których rozwiązanie jest w ludzkiej mocy" [Bauman 2000: 290]. Łagodzenie ontologicznych niepokojów stało się przynależne czasowi wolnemu. Aktywność religijna należy dziś w dużej mierze do zajęć nieregulowanych, osobistych i intymnych. Niewątpliwie przyczyniły się do tego trzy strategie: procesy i czynności związane $\mathrm{z}$ umieraniem i śmiercią zostały poddane podziałowi pracy (przekazane w ręce specjalistów) i odseparowane od codziennego doświadczenia; totalną perspektywę śmierci zastąpiono niezliczonymi niebezpieczeństwami dla życia; umieranie przyjęło postać „gry”, obecnej w rzeczywistości wirtualnej, a w wypadku ludzi bliskich ograniczonej do sfery prywatności. Natomiast życie przedśmiertne, egzystencja „tu teraz” wypełniła się niepewnością [Bauman 2000: 294-302]. W społeczeństwie konsumpcyjnym dostępność przeżyć szczytowych (peak experiences) czyni się dziś ideałem dla zwykłych ludzi. Skoro można je sprowadzić do opanowania właściwych technologii, nic nie stoi na przeszkodzie (twierdzą niektórzy) by odłączyć je od substancjalnie ukierunkowanych zainteresowań religijnych i skierować w stronę treści inkluzywnych, otwartych ma to co immanentne.

Czy religia rzeczywiście utraciła znaczenie w świecie późnej nowoczesności? A jeśli nie, to czy jest w stanie dopomóc w kanalizowaniu współczesnych zgryzot i cierpień? Niewątpliwie, głębokie przeobrażenia społecznej organizacji ludzkiego świata i zadań życiowych spowodowały rozproszenie sacrum i jego strukturalne przekształcenia. Jednak nie wydaje się, by zasadnicze funkcje pełnione przez 
religię uległy atrofii. Stosowanie przez kulturę popularną środków „znieczulających", podporządkowanych konsumpcji, nie tylko nie rozwiązało podstawowych problemów egzystencjalnych ludzkości: przygodności, cierpienia, śmierci, lecz wręcz przesłoniło ich rzeczywisty wymiar. Niezbywalne wartości, które ukształtowały naszą cywilizację, takie jak: godność osoby ludzkiej, zasada równości, wolność sumienia i religii, a bardziej ogólnie - prawa człowieka, leżące u podstaw świeckiego prawodawstwa demokratycznych społeczeństw, są jednocześnie rudymentarnymi kategoriami religii chrześcijańskiej. Jednak, jak zauważa Gianni Vattimo, „znaczenie chrześcijaństwa jako zbawczego (odkupiającego) przesłania zawiera się przede wszystkim $\mathrm{w}$ rezygnacji $\mathrm{z}$ kategorycznego roszczenia do «rzeczywistości»" [Vattimo 2013: 242]. W innym bowiem przypadku grozi nam popadnięcie w zgubny realizm, obiektywizm i jego następstwa w postaci różnych form autorytaryzmu czy idolatrii ustanawianych przez prawa rynku, żądania technokratów i ekspertów czy roszczenia prawa naturalnego. Zdaniem Vattimo, " (...) jedyna prawda jaka została objawiona w Piśmie Świętym, to wezwanie do życia w zgodzie z prawdą miłości, prawdą miłosierdzia" [Vattimo 2013: 243]. Podobnego zdania jest polski politolog Jan Grosfeld, autor wielu prac o tematyce teologiczno-społecznej, dla którego chrześcijanin to ktoś, kto działa na płaszczyźnie mikrostrukturalnej i nie ucieka od krzyża, „ (...) kto uśmiecha się pośród bólu i ciemności, bo widzi blask Chrystusa-Króla i chwyta się Jego płaszcza" [Grosfeld 1996: 188]. Trudno zatem pogodzić się z możliwością redukcji sacrum religijnego wyłącznie do wymiaru ethosowego, choć pokusa instrumentalizacji wartości zawsze istnieje. Jan Grosfeld, wśród zagrożeń wymienia fundamentalistyczny sposób traktowania religii, który przybiera postać idolatrii (przykładem jest często stosowana triada Bóg-Honor-Ojczyzna, sytuująca na tym samym poziomie trzy nierówne elementy i tym samym oddalająca się od judeochrześcijańskiej wizji Boga i człowieka), dalej - konsumpcjonizm i populistyczny cynizm, utopizm i pragmatyzm, a także religijność zbudowaną na lęku [Grosfeld 2011: 240-247].

W wymiarze makrostrukturalnym, na rzecz religii przemawiają argumenty odwołujące się do postępującej polaryzacji struktury społecznej w skali globalnej - z jednej strony rośnie liczba ludzi biednych, żyjących na progu minimum egzystencji, z drugiej zaś powiększają się dochody najbogatszych. Przeobrażeniu podlega także klasa średnia (jakiekolwiek łączą się z tym terminem problemy interpretacyjne), której członkowie realizując projekty tzw. „sztuki życia” mogą sięgać do arsenału tradycyjnych symboli religijnych i obudowywać je nowymi wzorami konsumpcji. Religia może zatem przyczyniać się do stabilizacji osiągniętego przez nich statusu. $Z$ drugiej strony - ludzie znajdujący się na przeciwnym biegunie 
zamożności i prestiżu, szukają niejednokrotnie w religii przeżyć emocjonalnych i sposobności zaangażowania moralnego. Jak dowodzą Pippa Norris i Ronald Inglehart, wysoki wskaźnik dzietności w słabo zmodernizowanych społeczeństwach (a zarazem malejący w wysoko rozwiniętych), wpływa na powiększanie się liczby ludzi o tradycyjnych poglądach religijnych w skali globalnej [Norris, Inglehart 2006]. Zarazem, jak sugerował kardynał Stefan Wyszyński, przekroczenie progu nędzy ekonomicznej łączy się z radykalnym spadkiem religijności w jej typowych wymiarach rytualnych, moralnych, obyczajowych i wspólnotowych [por. Wójtowicz 2004: 272].

Niewątpliwie wielu niedoszłych konsumentów, z przypisaną etykietą „zbyteczności”, staje przed pokusą ucieczki od „przekleństwa wyboru” i schronienia się pod skrzydłami rozmaitych fundamentalizmów. Ceną jest scedowanie prawa do decyzji na zbiorowość i bezwzględne jej podporządkowanie. Samuel Huntington, trafnie prognozował (w kontekście współczesnych ruchów społecznych, w tym migracji), że religia upolityczniona, stając się ekskluzywna i absolutna, będzie stanowić jedno z wielkich zagrożeń dla demokracji i pokojowego współistnienia cywilizacji [Hunington 1997]. Jeśli jednak możliwe stałoby się ukierunkowanie systemów religijnych na wymiar etyczny (B.Tibi), to czy wpłynęłoby to na sposób prowadzenia dyskursu, pomimo widocznych różnic światopoglądowych? [Tibi 1997: 150-151]. Dotychczas udzielane odpowiedzi nie wydają się być satysfakcjonujące, zwłaszcza dla globalnych graczy politycznych i ekonomicznych. Z drugiej strony, patrząc na religię przede wszystkim w kontekście lokalnym, należy uznać, że ma ona szansę zostać siłą prowadzącą do uczynienia naszego, pełnego niepokoju świata bardziej znośnym i przyjaznym dla jego mieszkańców.

\section{O pożytkach $\mathrm{z}$ socjologii religii}

Socjologia religii jako dyscyplina naukowa znajduje się obecnie w sytuacji niezwykle trudnej, a zarazem delikatnej. Po pierwsze, brak satysfakcjonującej wszystkich definicji religii nie zwalnia z posiadania wyraźnie sprecyzowanych koncepcji granic obszaru problemowego, który poddaje się analizie. Badacze nie są zgodni w kwestii identyfikacji zjawisk religijnych i ustalenia różnic między tym, co religijne, pozbawione wszelkiego aspektu religijnego, czy też „religijne inaczej”. Polska socjologia religii pozostaje pod silnym wpływem społeczno-kulturowego kontekstu chrześcijaństwa (zwłaszcza katolicyzmu) oraz treści zjawisk religijnych, uwzględniających kulturę religijną (wartości, symbole, znaczenia) i sposoby zachowań, odwołujące się do kategorii „rzeczywistości nie-empirycznej”, świata sacrum o charakterze transcendentnym. Dzięki temu religijny system wierzeń, wartości 
i czynności religijnych można odróżnić od analogicznych systemów politycznych, czy ideologicznych lub zjawisk identyfikowanych przez niektórych socjologów na płaszczyźnie „funkcjonalnych równoważników” jako substytuty religii. Uważają oni, że zjawiska takie jak: komunizm, nazizm, czy świecki humanizm mogłyby być interpretowane w sposób religijny. Podobne sugestie wysuwa Thomas Luckmann, uznając za obszar współczesnego sacrum tematykę seksualności i życia rodzinnego, etos mobilności czy różnorodne przejawy jednostkowej samorealizacji [por. Luckmann 1996: 155]. Niewątpliwie sama kategoria sacrum pojawiająca się na gruncie socjologii, czy antropologii kulturowej posiada znacznie szerszą konotacją niż w obszarze filozofii religii. Na podstawowym poziomie pozwala określić jako święte wszystko to, co w danej kulturze ma wartość nadrzędną, na nieco wyższym - oznacza system wierzeń religijnych, Ostatecznych Świętych Założeń związanych z rytuałami (R. Rappaport), a na najwyższym - sacrum tworzy osobny rodzaj rzeczywistości, dostępny jedynie poprzez indywidualne doświadczenie religijne [por. Mielicka 2000: 267, 270].

W analizie socjologicznej, religia może być reprezentowana bądź jako zmienna niezależna, wpływająca na różne dziedziny życia społecznego, np. politykę, gospodarkę, obyczajowość, sztukę, bądź jako zmienna zależna - przejaw tego, co społeczne, który na najogólniejszym poziomie tworzy symboliczne reprezentacje problemu sensu życia, znajdujące wyraz w unormowanych interakcjach (społeczność religijna) i oddziałujące na jednostki poprzez internalizację modeli kulturowych [Piwowarski 1996: 43-44]. Tak ujęta religia łączy się z możliwością badania za pomocą określonych parametrów, co pociąga za sobą pewną arbitralność, budzącą zrozumiałe wątpliwości. W prowadzonych analizach nadal dominuje odniesienie do instytucjonalnego modelu katolicyzmu. Zakłada on stosowanie ilościowych wskaźników werbalnych i obserwacyjnych, dotyczących: globalnego wyznania wiary, wiedzy religijnej, przekonań, doświadczenia religijnego, uczestnictwa w praktykach obowiązkowych i nadobowiązkowych, więzi ze wspólnotą religijną, moralności. Jednak procesy zachodzące w zmodernizowanych społeczeństwach, powiązane z procesem indywidualizacji i pluralizacji sceny religijnej, skłaniają do coraz szerszego stosowania jakościowych metod badawczych, opartych na analizie biograficznej, wywiadach pogłębionych czy obserwacji uczestniczącej, a studia empiryczne coraz częściej odwołują się do strategii triangulacyjnych [m.in. Grotowska 1999; Sroczyńska 2013; Tyrała 2014].

We współczesnych naukach socjologicznych coraz częściej akceptowane jest współistnienie zróżnicowanych paradygmatów w badaniu zjawiska religii, m.in. 
sekularyzacyjnego, indywidualizacyjnego czy pluralistycznego [por. Pollack, Müller, Pickel 2012]. Zarówno „fascynacja”, jak i „odczarowanie” towarzyszą obecności religii w złożonych kontekstach społeczno-kulturowych dzisiejszego świata i Kościoły, i związana z nimi religijność w silnie zmodernizowanych społeczeństwach, choć nie unikają wpływów i konsekwencji procesów sekularyzacyjnych pełnią nadal, w warunkach pragmatyzacji wartości, rolę spójnego źródła wartości publicznych (zwłaszcza zaufania i wiarygodności) oraz wspólnej przestrzeni moralnego dyskursu, niezbędnego w procesach socjalizacji [Wójtowicz 2004: 302]. Zastosowanie nowych perspektyw badawczych pozwala na wyjaśnianie wielorakich przemian religijności we współczesnym świecie [Mariański 2006: 71-76; Mariański 2010]. Sekularyzacja związana ze słabnięciem i dekonstrukcją religijności kościelnej nie jest bowiem jedynym procesem związanym z modernizacją. Paradoksalnie, właśnie w warunkach ponowoczesności dochodzi do ożywienia potrzeby sensu, jedności, tożsamości, a co za tym idzie do stworzenia nowych pól religijnych, będących odpowiedzią na dewastację symbolicznego dziedzictwa, w tym barbaryzację obyczajów.

Pewne kontrowersje (dziś coraz rzadsze) pojawiają się w związku z rozpatrywaniem możliwości i barier współpracy socjologii religii z innymi naukami religiologicznymi. Sugestia ta dotyczy przede wszystkim filozofii religii i teologii, psychologii religii, historii i antropologii kulturowej. Dialog ułatwia przyjęcie stanowiska, że twierdzenia naukowe nie wchodzą $\mathrm{w}$ konflikt $\mathrm{z}$ wewnętrzną prawdą religii, którą ona prezentuje. Każda $\mathrm{z}$ dyscyplin winna szanować własny przedmiot badań, korzystać z dorobku innych i nie rościć pretensji do orzekania o całokształcie fenomenu religii [Bronk 1996: 148-151]. Dla socjologii religii szczególnie ważna jest współpraca z innymi subdyscyplinami socjologicznymi, m.in. socjologią kultury, moralności, wychowania, organizacji, czy polityki. Religia i społeczeństwo pozostają bowiem w relacji dwustronnej, a w życiu codziennym konkretyzuje się empiryczny wymiar religii, która w przeciwnym razie byłaby czymś nieuchwytnym dla badacza.

W przekonaniu wielu polskich socjologów, najlepiej udokumentowana wydaje się być hipoteza wielokierunkowych zmian w dziedzinie religijności, zgodnie z którą tradycyjne i nowoczesne wartości koegzystują w świadomości zbiorowej Polaków. Dekompozycja religijności kościelnej wiążąca się z „pełzającą” (a od dekady przyspieszającą sekularyzacją), nie wyklucza różnych przejawów jej rekompozycji lub powstawania wspólnotowych formacji, znajdujących miejsce w nowych ruchach i stowarzyszeniach religijnych. Zgodnie z postulatami teorii rynkowej, 
procesy dyferencjacji i indywidualizacji prowadzą także do ożywienia kapitału religijnego i społecznego na poziomie sekt, ruchów kultowych (o rodowodzie orientalnym) i kultów zorientowanych na klienta, ich oddziaływanie w społeczeństwie polskim pozostaje jednak ograniczone [por. Mariański 2018].

\section{O scenariuszach przyszłości}

Socjologowie zgodni są w opinii, że przyspieszające, choć nierównomierne w różnych sferach życia procesy o charakterze modernizacyjnym (lat 90 . XX i pierwsza dekada XXI w.) i postmodernizacyjnym ustanowiły warunki kształtowania się nowych wzorów i kategorii religijności. Różnorodność zmian komplikuje odpowiedź na pytanie o przyszłość życia religijnego. W społeczeństwie polskim obserwuje się duże zapotrzebowanie na rekonstrukcję symbolicznego świata, w którym wartości tradycyjne (religijne) spotykają się z nowoczesnymi. Czas pokaże, czy Polacy zdołają z tego depozytu uczynić siłę zdolną do reorganizacji postaw i zachowań, czy też zadowolą się religią jako faktem obyczajowym, częściowo odtwarzającym elementarne struktury społeczne. W tym miejscu warto zastanowić się nad miejscem wartości religijnych w globalizującym się świecie, przede wszystkim w ramach projektu europejskiego. Nie ulega wątpliwości, że w sytuacji, gdy treści kulturowe o podłożu transcendentnym (ogniskujące się wokół zasady solidarności, braterstwa i miłości) przeciwstawiają się modelowi opartemu na technologii i rynku, potrzebne jest zachowanie czujności i krytycyzmu wobec środków i uprzywilejowanych celów. Religie, szukając swojego miejsca w zsekularyzowanych społeczeństwach, próbują ponownie odzyskać sferę publiczną, wykorzystując tradycyjne zasoby kulturowe i strukturalne (np. rodzinę, wspólnotę narodową czy tożsamość płciową) oraz umiejętność artykułowania problemów w kategoriach globalno-lokalnych. Zdaniem niektórych badaczy (np. P. Sloterdijka) wielkie religie powinny zawrzeć przymierze z zsekularyzowanymi państwami i wspólnie bronić ludzkości przed największymi zagrożeniami, co może oznaczać, że „Ewangelia stanie się raportem o stanie naturalnego środowiska i protokołem dotyczącym sytuacji praw człowieka" [Sloterdijk 2008: 12-13].

Jakkolwiek nie brzmiałoby to kontrowersyjnie, ważne jest pytanie, czy polskiemu katolicyzmowi uda się nadal zachować pozytywne, żywotne cechy w sytuacji wyznaniowej dominacji. Odpowiedź twierdząca wiąże się z koniecznością większej otwartości Kościoła wobec oczekiwań społeczeństwa pluralistycznego, jednak bez rezygnacji ze swojej tożsamości. Znany socjolog José Casanova zachęcał Polaków, aby pokazali, że nowoczesność i katolicyzm mogą bardzo dobrze ze sobą współistnieć. Jego zdaniem Polacy mogą wpłynąć na kształt tego kontynentu 
właśnie dzięki temu, że będą katolikami, Europejczykami i dobrymi obywatelami [Casanova 2005]. $Z$ drugiej strony, trudno nie dostrzec racji przemawiających za odmiennym stanowiskiem, choćby prezentowanym przez Petera Bergera czy Marcela Gaucheta, zgodnie z którym jeszcze niedawno religia pomagała budować wspólnotę, a dziś wyznawcy poszukują w wierze samych siebie. Pewną troską socjalizacyjną może zatem napawać powiększanie się luki pokoleniowej, zwłaszcza w świecie chrześcijańskim, co pokazują międzynarodowe badania prowadzone w 106 krajach [The Age Gap in Religion Around the World]. Wśród młodych między 18 a 39 rokiem życia zmniejsza się ważność religii w perspektywie życiowej, znaczenie codziennej modlitwy i uczestnictwa w praktykach. Szczególnie widoczne staje się to w dwóch najmłodszych kohortach Polaków, urodzonych po roku 1980 [Grabowska 2018: 172-188].

Leszek Kołakowski uważał, że prawdziwych chrześcijan było zawsze niewielu, toteż tych którzy biorą religię „na serio”, niezależnie od koniunktury społeczno-politycznej, obecna sytuacja nie powinna dziwić [Kołakowski 1984: 158-164]. Należy raczej zaakceptować stan permanentnego kryzysu chrześcijaństwa i docenić wyjątkowość związku religii i Kościoła z historyczną, i współczesną kondycją społeczeństwa polskiego, pamiętając o tym, że „Skoro trendy nie są czymś nieuchronnym, od nas niezależnym, to możemy mieć w tych procesach swój udział: po tej lub po tamtej stronie” [Grabowska 2018: 221].

\section{Bibliografia:}

Bauman Z. (2000), Globalizacja. I co z tego dla ludzi wynika, PIW, Warszawa.

Bauman Z. (2000), Ponowoczesność jako źródło cierpień, Wyd. Sic!, Warszawa.

Bronk A. (1996), Nauka wobec religii (teoretyczne podstawy nauk o religii), KUL, Lublin.

Casanova J. (2005), Religie publiczne w nowoczesnym świecie, Zakład Wydawniczy Nomos, Kraków.

Chlewiński Z. (red.) (1982), Psychologia religii, Wyd. KUL, Lublin.

Durkheim E. (1990), Elementarne formy życia religijnego. System totemiczny w Australii, Wyd. Naukowe PWN, Warszawa.

Grabowska M. (2018), Bóg a sprawa polska. Poza granicami teorii sekularyzacji, Wyd. Naukowe Scholar, Warszawa.

Grosfeld J. (2011), Od lęku do nadziei. Chrześcijanie, Żydzi, świat, Wyd. WAM, Kraków. Grosfeld J. (1996), O pokusie zejścia z krzyża, Oficyna Wydawnicza „Vocatio”, Warszawa. Grotowska S. (1999), Religijność subiektywna. Studium socjologiczne na podstawie wywiadów narracyjnych, ZW Nomos, Kraków. 
Huntington S. (1997), Zderzenie cywilizacji i nowy kształt ładu światowego, Wyd. Muza, Warszawa.

Kołakowski L. (1987), Jeśli Boga nie ma... O Bogu, Diable, Grzechu i innych zmartwieniach tak zwanej filozofii religii, Aneks, Londyn.

Kołakowski L. (1984), O tak zwanym kryzysie chrześcijaństwa, w: Kołakowski L., Czy diabet może być zbawiony i 27 innych kazań, Aneks, Londyn.

Luckmann Th. (1996), Niewidzialna religia, Zakład Wydawniczy Nomos, Kraków.

Malinowski B. (1990), Mit, magia, religia, Dzieła, t. 7, Wyd. Naukowe PWN, Warszawa.

Mariański J. (2018), Kościót katolicki w Polsce w kontekście społecznym. Studium socjologiczne, Wyd. Naukowe PWN, Warszawa.

Mariański J. (2010), Religia w społeczeństwie ponowoczesnym. Studium socjologiczne, Oficyna Naukowa, Warszawa.

Mariański J. (2006), Sekularyzacja i desekularyzacja w nowoczesnym świecie, ZW KUL, Lublin.

Mielicka H. (2000), Antropologia świąt i świętowania, Wyd. AŚ, Kielce.

Mikołejko Z. (2014), Religia bez właściwości, w: Chachulski T., Snopek J., Ślusarska M. (red.), Religijność w dobie popkultury, Wyd. UKSW, Warszawa.

Norris P., Inglehart R. (2006), Sacrum i profanum. Religia i polityka na świecie, Zakład Wydawniczy Nomos, Kraków.

Otto R. (1993), Świętość: elementy irracjonalne w pojęciu bóstwa i ich stosunek do elementów racjonalnych, Thesaurus Press, Wrocław.

Piwowarski W. (1996), Socjologia religii, KUL, Lublin.

Pollack D., Müller O., Pickel G. (eds.) (2012), The Social Significance of Religion in the Enlarged Europe: Secularization, Individualization and Pluralization, Ashgate, Farnham/Burlington.

Sloterdijk P. (2008), Otwarta jest tylko droga cywilizacyjna, „Dziennik” nr 3.

Sroczyńska M. A. (2013), Rytuały w młodzieżowym świecie. Studium socjologiczne, Wyd. FALL, Kraków.

Tibi B. (1997), Fundamentalizm religijny, PIW, Warszawa.

The Age Gap in Religion Around the World, http://www.pewforum.org/2018/06/13/ the-age-gap-in-religion-around-the-world [dostęp:8.10.2018].

Tyrała R. (2014), Bez Boga na co dzień. Socjologia ateizmu i niewiary, ZW Nomos, Kraków. Vattimo G. (2013), Wiek interpretacji [The Age of Interpretation], fragment, thum. Olszewski T., w: „Przestrzenie Teorii” nr 20, Wyd. UAM, Poznań.

Wójtowicz A. (2004), Wspótczesna socjologia religii. Założenia, idee, programy, WSS-G, Tyczyn.

Zdybicka Z. J. (1978), Człowiek i religia: zarys filozofii religii, Redakcja Wydawnictw KUL, Lublin. 